\title{
"PROPORTIONALITY TEST" IN THE LEGAL REGULATION OF RESTRICTION AFTER THE TERMINATION OF PUBLIC SERVICE CAREER: SEARCH FOR AN OPTIMAL MODEL
}

\begin{abstract}
Purpose - the substantiation of the expediency to set restriction after the termination of the public service career, which is based on "the proportionality test", distinguishing the unified standards for the consolidation of its elements.

Research methods. The paper is executed by applying the general research and special methods of scientific cognition. The dialectical method, as a basic one, allows the author to find out the essence of proportionality test, its narrow and broad sense, to justify its fundamental value for the model of legal regulation of a relevant restriction. The Aristotelian method makes it possible to study the challenging issues of standardizing the principles of its restriction that has caused "defectiveness" of its comprehension and application. Using the logical-semantic method, the author specifies the concepts list, comparativelegal-special features of perception of elements of the proportionality test in the rulemaking practice of countries of the world. Using the forecasting and modeling - the proposals on basic standards of the model of the relevant legal regulation are formulated.

Results. The article analyses the basic doctrinal approaches for the understanding of proportionality test, its narrow and broad versions, justifies its basic role for the shaping of a model of legal regulation of the restriction as an instrument for corruption prevention in the legal area. Based on the analysis of rulemaking practice of countries of the world, it is proved the availability of a steady trend towards the perception (non-system, differing degree of the manifestation and consolidation) of the elements of proportionality test in the legal regulation of the restriction, which has resulted in excessive interference in the private autonomy of an individual, discrimination of the latter. The author marks particular cases of the subject-related rulemaking practice of different countries and renders the standards of the model of legal regulation of the restriction.
\end{abstract}

Conclusions. In the context of active use of a unique resource of the restriction after the termination of public service career as an instrument for corruption prevention in the private sector, "the proportionality test" in its broad sense, as the mix of several obligatory complex elements, should be the basis for shaping model of its legal regulation which is perfect in content and effective in use. The author proposes to consider the following as the standards of such regulation: 1) legislative (along with a simultaneous correlation with the codes of conduct for public servants) consolidation of the provision of absolute determination of the content (excluding the opportunity to use evaluative provisions) towards all elements of the mechanism of the specific restriction; 2) absolute determinacy of the fixed basic standards-definitions; 3) unification of the provisions about the subject of restriction with the elimination of any preconditions for possible discrimination; 4) specification of the scope for interference including "the former" public service of an individual, as well as the minimization of restriction validity (one year); 5) standardization of the provisions on the legitimate goal of the restriction, the content of which is relevant to all elements of the latter; 6) detailed elaboration of the regulation of the procedure for the individual's employment after the termination of public service career; 7) corresponding tie between a subtle provision and instructions of guaranteeing appeals and redress related to the use of the restriction resource.

Key words: private sector corruption, filter, expediency, need, balance between public and private interests, legislation, standards, elements. 


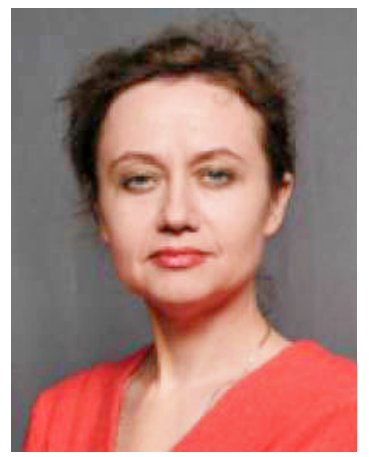

Tetiana Kolomoets, Dean of Law Faculty of the Zaporizhzhya National University, Doctor of Law, Professor, Corresponding Member of the National Academy of Legal Sciences of Ukraine, Honoured Lawyer of Ukraine orcid.org/0000-0003-1101-8073 t_deputy@ukr.net

\section{Introduction}

In the context of searching for effective instruments for corruption prevention in the private sector, the interested community should focus on the unique kind of "anti-corruption" restriction - the restriction after the termination of public service career. Despite the available practice of different countries of the world in regulatory consolidating of the principles of its application as well as the provisions of international legal acts in terms of the implementation of this kind of restriction, unfortunately, it is impossible to hold its designated purpose effective. Moreover, the variability of perception of international subject-related regulations and the formulation of the national practice in the specific rulemaking, thus the application, confirm the multiple cases of its "defective" identification with an opportunity of legitimate coercive arbitrary interference in "private autonomy of the individual", discrimination based previous employment of the person etc. The lack of a unified model of standardized nature regarding the regulation of the principle of the restriction's use negatively affects the comprehension of the essence, aim and specifics of this type of "anti-corruption" restriction, causes the inconsistency and "defectiveness" of its use, as the very instrument for corruption prevention, and mainstreams the search for the universal "basic" foundation which would permit consolidating the entire uniqueness of the restriction and unifying the top priorities of the subject-related national rulemaking and law enforcement. "Proportionality test" may act as that sort of foundation, which will make it possible to define the limits of a balanced, guaranteed, legitimate, burdensome, intrusive use of the restriction, thereby stipulating its effectiveness as a means of corruption prevention in the private sector. The model shaping is directly connected with the renewal of its scientific basis related to the understanding of "proportionality test" and restriction after the termination as a type of "anticorruption" restriction. Disappointingly, there are no complex researches exclusively devoted to the relevant subject-matter. At the same, the individual issues of "proportionality test" were covered in the papers of S. Pohrebniak, S. Venher, S. Shevchuk, S. Holovatyi, T. Fulei, M. Luchenko et al., the problems of "anti-corruption restrictions" - in the papers of O. Dudorov, K. Berdnykova, S. Kushnir, M. Khavroniuk, O. Mykolenko et al., and the foreign practice of their application - in the papers of F. Fluri, M. Villoriia, S. Synnestrom, Ya. Bertok, S. Zymneva, A. Chumakova et al. 
There are few papers which highlight the challenges of combining anti-corruption subject-matter and "proportionality test" (for example, the contributions of V. Kolpakov); however, they are also characterized by other purposes. All of this causes the set of article's goal which involves substantiating the efficiency following available sources, shaping the model of legal regulation of restriction after the termination of public service career that should be based on "the proportionality test", highlighting the unified standards on the fixation of its elements. The article is elaborated through using both general research and special methods of scientific cognition, the combination of which permits the author to reach the specified purpose, guarantee the comprehensive nature of the study of subjectmatter as well as the veracity and credibility of results. Due to the use of the dialectical method as a basic one, it is found out the essence of "proportionality test", its "narrow" and "broad" understanding, and its "basic" essence for restriction after the termination of public service career in shaping the model of legal regulation of the latter is substantiated. The Aristotelian methods are applied while processing source subject database, detecting challenging aspects of standardizing principles of the use of the restriction resource. The logical-semantic method makes it possible to extend, specify the conceptual topical list, comparative-legal method - to compare the features of the experience of different countries of the world in perceiving of individual elements of "proportionality test" in the legal regulation of the restriction after the termination of public service career. By utilizing the methods of forecasting and modeling, the author makes recommendations for "basic standards" of shaping a relevant model of the legal regulation.

\section{2. "Proportionality test": fundamental professional doctrinal approaches to the comprehension}

The majority of available professional scientific resources link "proportionality test" (the following is considered as synonyms: "principle of proportionality", "proportionality", "doctrine of proportionality", "theory of proportionality" etc.) with the rule of law and justice and define it as "the guarantee of balance between public and private interests $\langle\ldots>$ in cases $<\ldots>$ of the conflict of such interests" ; "a balance between public and private interests $<\ldots>$ in cases of possible restriction of the individual's rights by the state authorities"2; "a balance of interests when the goals of restriction of the individual's rights are essential and the means for their achievement is minimally burdensome for the individual"";; "smart measures (applicable, necessary, commensurate)

${ }^{1}$ Totskyi, B.A. (2013). Proportionality test: historical aspect and theoretical components. Journal of Kyiv University of Law, no. 3, pp. 70-74 [Тоцький Б.А. Принцип пропорційності: історичний аспект і теоретичні складові. Часопис Київського університету права. 2013. № 3. C. 70-74].

${ }^{2}$ Totskyi, B.A. (2013). Proportionality test: historical aspect and theoretical components. Journal of Kyiv University of Law, no. 3, pp. 70-74 [Тоцький Б.А. Принцип пропорційності: історичний аспект і теоретичні складові. Часопис Київського університету права. 2013. № 3. C. 70-74].

${ }^{3}$ Pohrebniak, S.P. (2012). Proportionality test in Ukrainian legal practice and the ECHR practice. Legal support of an effective use of decisions and application of the ECHR practice: collection of scientific articles of International scientific-practical conference (Odesa, March 15, 2012). Odesa: National University “Odessa Law Academy”, pp. 294-310 [Погребняк С.П. Принцип пропорційності в українській юридичній практиці та практиці ЄСПЛ. Правове забезпечення ефективного використання рішень $i$ застосування практики ССПЛ : збірник наукових 
for pursuing the legitimate public goal"4; "a correlation of authoritative influence on the private life $\langle\ldots\rangle$ with an idea of restriction of such authority $\langle\ldots\rangle$ while there are no alternatives to the coercive interference and minimization of the latter one (through means) taking into account of those variants, which are statutorily consolidated $<\ldots>$ for the achievement of a particular goal"5 etc. Thus, the analysis of the above provisions permits conditionally emphasizing two "basic" approaches to its understanding. The first is associated exclusively with a balance between (sometimes, it is used the words combinations "fair balance", "smart balance" public and private interests, thus its identification with "commensuration", "dimensionality", "proportionality"7. It may be considered as one providing the study of "proportionality test" in its narrow sense. Indeed, the second approach without taking exception against the importance of the relevant balance associates it with "substantiation", "determinacy", "the legitimacy of public goal", "minimal burdensomeness for the person whose rights are restricted"8 i. e. it is characterized by the review of "proportionality test" in its broad sense with highlighting of other important elements of its complex resource through eliminating the preconditions for its identification with a balance between public and private interests "at any cost", "under any circumstances", "in any way", etc. In the context of the inextricable connection between "proportionality test" and the rule of law, the consideration in the broad sense as a combination of several elements of its content is feasible and one that permits clarifying its real potential. What are these elements? Despite the diversity of doctrinal professional approaches to their name and consistency of presenting, one can touch upon the next "basic" model of their mix, which is formed taking into account the ECHR practice regarding the use of provisions of the European Convention on Human Rights and relative practice of the national judicial institutions of different countries of the world, namely:

статей Міжнародної науково-практичної конференції, м. Одеса, 15 березня 2012 р. / за заг. ред. С.В. Ківалова. Одеса : Національний університет «Одеська юридична академія», 2012. C. 294-310].

${ }^{4}$ Yevtoshuk, Yu.O. (2015). Proportionality test as an essential component of the rule of law (Extended abstract of candidate's thesis). Kуіv [Євтошук Ю.О. Принцип пропорційності як необхідна складова верховенства права : автореф. дис. ... канд. юрид. наук ; 12.00.01. Київ, 2015. 16 c.].

${ }^{5}$ Luchenko, M.M. (2019). Proportionality principle in administrative proceedings (Extended abstract of candidate's thesis). Zaporizhzhia [Лученко М.M. Принцип пропорційності в адміністративному судочинстві : автореф. дис. ... канд. юрид. наук : 12.00.07. Запоріжжя, 2019. 18 c.].

${ }^{6}$ Tatsii, V.Ya., Petryshyn, O.V. (eds.) (2017). Great Ukrainian legal encyclopedia: in 20 vol. Kharkiv: Pravo, vol. 3: General theory of law [Велика українська юридична енциклопедія : у 20 т. / редкол. : В.Я. Тацій, О.В. Петришин та ін. Харків : Право, 2017. Т. 3 : Загальна теорія права. 932 с.].

${ }^{7}$ Yevtoshuk, Yu.O. (2015). Proportionality test as an essential component of the rule of law (Extended abstract of candidate's thesis). Куіv [Євтошук Ю.О. Принцип пропорційності як необхідна складова верховенства права : автореф. дис. ... канд. юрид. наук ; 12.00.01. Київ, 2015. 16 c.].

${ }^{8}$ Totskyi, B.A. (2013). Proportionality test: historical aspect and theoretical components. Journal of Kyiv University of Law, no. 3, pp. 70-74 [Тоцький Б.А. Принцип пропорційності: історичний аспект і теоретичні складові. Часопис Київського університету права. 2013. № 3. C. 70-74]. 
first, relevance (sometimes the provisions on "expediency", "feasibility" are found) as a complex element which arranges justifiability (or "conformity") of legitimate (one should separate from legal) limit, legitimacy and legal certainty; second, a need which, in its turn, provides for the combination of "minimal" interference of the public entity in the "private autonomy of the individual" and the use of "less intrusive measures" 10 for such interference. At last, third, it takes place a balance between public and private interests, the guarantee of compensation of possible harm caused to the individual as the very interference in the "private autonomy of the individual", as well as its limits. Each of elements is "complex", complements each other and only in the aggregate forms that unique resource of "proportionality test" which makes it possible to consider it as a kind of "filter", on the one hand, for ensuring the implementation and protection of public interests during the professional activity of individuals authorized to perform the functions of the state or local government, as well as the instrument for corruption prevention in the private sector after its termination, and on the other hand, for preventing arbitrary interference in "the private autonomy" of such individuals.

\section{Restrictions for an individual after the termination of public service career as an area of "proportionality test" objectification}

Legal and regulatory framework of the relevant kind of "special" restriction is wellestablished by the international anti-corruption standard. The United Nations Convention against Corruption (art. 12) stipulates introducing of restrictions "in appropriate cases and for a reasonable time" 11 on the professional activity of the ex-officials in the private sector after their retirement, resignation or in case of other reasons if such activity is directly associated with the functions which individuals have performed during their career or which they have controlled ${ }^{12}$. Thus, the provisions defining the mentioned restriction as "an instrument for corruption prevention in the private sector" fixe its specific features which determine the unique nature of its recourse. At the same time, these provisions, as well as Recommendation № R (2000) 10 of the Committee of Ministers to Member states on codes of conduct for public officials, consolidate the elements of "proportionality test" as "standards" for the national rulemaking in terms of the regulation of the relevant issue the implementation of which, as the analysis of the legislation shows, is varying.

\footnotetext{
${ }^{9}$ Yevtoshuk, Yu.O. (2015). Proportionality test as an essential component of the rule of law (Extended abstract of candidate's thesis). Kуiv [Свтошук Ю.О. Принцип пропорційності як необхідна складова верховенства права : автореф. дис. ... канд. юрид. наук ; 12.00.01. Київ, 2015. 16 c.].

${ }^{10}$ UN Development Program in Ukraine (2016). Lifestyle monitoring: review of the international practice in Ukraine. Kуіv [Моніторинг способу життя: огляд міжнародної практики, можливість застосування в Україні / Програма розвитку ООН в Україні. Київ, 2016. 36 c.].

${ }^{11}$ Holovkin, B.M. (ed.) (2019). Corruption prevention: textbook. Kharkiv: Pravo [Запобігання корупції : підручник / Б.М. Головкін, В.Ф. Оболенцев, М.В. Романов та ін. ; за заг. ред. Б.М. Головкіна. Харків : Право, 2019. 296 с.].

${ }^{12}$ Holovkin, B.M. (ed.) (2019). Corruption prevention: textbook. Kharkiv: Pravo [Запобігання корупції : підручник / Б.М. Головкін, В.Ф. Оболенцев, М.В. Романов та ін. ; за заг. ред. Б.М. Головкіна. Харків : Право, 2019. 296 с.].
} 
Hence, when regulating the specific issue, as a rule, the legislator solidifies the provisions either in the "basic" anti-corruption legislative act (for example, the experience of Ukraine, Georgia) or the legislative act on the public service (for example, the experience of Germany) or duplicates these provisions in the acts, which accumulate moral and ethical principles for the conduct of individuals entrusted with public powers (for example, Netherlands, Slovakia) when choosing one of the mentioned alternatives. At the same time, the degree of detailed elaboration of the provisions also varies: from general definitions, incl. the use of evaluative provisions, to the defined rules. The latter option is the best one (it can be defined as ideal) under the conditions of searching for an optimal model of legal regulation of the relation directly connected with the use of restriction resource, because it is ensured the unification of their interpretation and application and the practice of the latter is formed due to the totally defined rules, which are similar in terms of content and according to text.

Restriction after the termination of public service career (however, in the legislation of different countries, there are provisions on "restriction after the termination of executing activity related to the performance of functions of the state or local government"13, "restriction on employment in the private or non-governmental sectors after the dismissal from public office"14, "restriction on employment after the dismissal from office" 15 , "restriction on the professional activity of the former civil servants in the private sector" 16 etc. is oriented towards the special entity who is, unlike the entities of other "anti-corruption" restrictions, "former" public servant, "an individual who held political, public post", "ex-public servant", "ex-official". The specific nature of that kind of entity is caused by the lack of his connection with professional activity, which is related to the performance of the functions of the state or local government, and relevant

${ }^{13}$ Kolomoiets, T.O. (ed.) (2019). Restrictions for persons authorized to perform the functions of the state or local self-government as a means for prevention of the conflict of private and public interest: legal aspect: scientific and practical essay. Zaporizhzhia: Helvetyka [Обмеження для осіб, уповноважених на виконання функцій держави або місцевого самоврядування, як засіб запобігання конфлікту приватного та публічного інтересу: правовий аспект : науковопрактичний нарис / Т.О. Коломоєць, Р.О. Кукурудз, С.М. Кушнір ; за заг. ред. Т.О. Коломоєць. Запоріжжя : Видавничий дім «Гельветика», 2019. 80 с.].

${ }^{14}$ Villoriia, M., Synnestrom, S., Bertok, Ya. (2010). Civil service ethics: prevention of conflict of interests and requirements for the legislation. Kyiv: Center for Civil Service Adaptation to EU Standards [Віллорія М., Синнестрьом С., Берток Я. Етика державної служби: запобігання конфлікту інтересів та вимоги до законодавства / пер. з англ. І.С. Чуприни. Київ : Центр адаптації державної служби до стандартів ЄС, 2010. 104 с.].

${ }^{15}$ Suslova, I.M., Fluri, F., Badrak, V.V. (eds.) (2017). Parliamentary ethics in Ukraine. Realities of the needs, prospects (according to the research of the NGO "Center for Army, Conversion and Disarmament Studies" and the Institute of Social Technologies "Sociopolis"). Geneva, Kyiv [Парламентська етика в Україні. Реалії потреби, перспективи (за матеріалами дослідження ГО «Центр досліджень армії, конверсії та роззброєння» та Інституту соціальних технологій «Соціополіс») / пер. $з$ англ. за заг. ред. І.М. Суслової, Ф. Флурі, В.В. Бадрака. Женева ; Київ, 2017. 56 c.].

${ }^{16}$ Villoriia, M., Synnestrom, S., Bertok, Ya. (2010). Civil service ethics: prevention of conflict of interests and requirements for the legislation. Kyiv: Center for Civil Service Adaptation to EU Standards [Віллорія М., Синнестрьом С., Берток Я. Етика державної служби: запобігання конфлікту інтересів та вимоги до законодавства / пер. з англ. І.С. Чуприни. Київ : Центр адаптації державної служби до стандартів СС, 2010. 104 с.]. 
special legal status. At the same time, the legislation of different countries of the world involves a variable approach to the identification of the entity: with the application of restriction to any public servants (for example, the experience of Ukraine, Poland), with the division of entities into certain types (for example, the experience of Portugal, Spain), with "binding" to a particular "former" post (for example, the experience of Canada), an establishment (agency) where they performed their duties at the moment of career termination (for example, the experience of France). It is more expedient to extend this restriction, taking into account its essence", to all individuals who were empowered to perform the functions of the state of local government thus eliminating the preconditions for any discriminative manifestations.

The relevant restriction focuses exclusively on the professional activity of the individual after the termination of public service career, hence, its recognition as "an instrument for corruption prevention in the private sector" 17 for the achievement of a goal, as follows: " $<\ldots$..> risk minimization of conflict of interests under the servant's transfer to other work which is not connected with the performance of the functions of the state, local government" 18 , elimination of the preconditions for the creation of "favourable perspective post" by the individual in an illegal way"19 through using benefits of the public service and "prevention of dishonest use of coats by the former servant when exercising his representative functions" ${ }^{20}$. In other words, it is expected that after the termination of the public service career, the individual will forgo "inadequate use of benefits $\langle\ldots>$ of the service or post, which $<\ldots>$ has been held" 21 and being in the employment, he will adhere to all principles of the latter and will not "focus" on planning, using service benefits of his future workplace in the private sector. Despite the varying definitions of the restriction's target in the legislation of different countries, they are typical in content, however, with a diverse degree of provisions specification (from the general "corruption prevention in the private sector" (that is excessively generalized provision) to the division under individual components of restriction content). In any case, the analysis of specific provisions confirms the attempt to consolidate the focus of restriction on the achievement of a legitimate purpose.

${ }^{17}$ Holovkin, B.M. (ed.) (2019). Corruption prevention: textbook. Kharkiv: Pravo [Запобігання корупції : підручник / Б.М. Головкін, В.Ф. Оболенцев, М.В. Романов та ін. ; за заг. ред. Б.М. Головкіна. Харків : Право, 2019. 296 с.].

${ }^{18}$ Holovkin, B.M. (ed.) (2019). Corruption prevention: textbook. Kharkiv: Pravo [Запобігання корупції : підручник / Б.М. Головкін, В.Ф. Оболенцев, М.В. Романов та ін. ; за заг. ред. Б.М. Головкіна. Харків : Право, 2019. 296 с.].

${ }^{19}$ Holovkin, B.M. (ed.) (2019). Corruption prevention: textbook. Kharkiv: Pravo [Запобігання корупції : підручник / Б.М. Головкін, В.Ф. Оболенцев, М.В. Романов та ін. ; за заг. ред. Б.М. Головкіна. Харків : Право, 2019. 296 с.].

${ }^{20}$ Holovkin, B.M. (ed.) (2019). Corruption prevention: textbook. Kharkiv: Pravo [Запобігання корупції : підручник / Б.М. Головкін, В.Ф. Оболенцев, М.В. Романов та ін. ; за заг. ред. Б.М. Головкіна. Харків : Право, 2019. 296 с.].

${ }^{21}$ Villoriia, M., Synnestrom, S., Bertok, Ya. (2010). Civil service ethics: prevention of conflict of interests and requirements for the legislation. Kyiv: Center for Civil Service Adaptation to EU Standards [Віллорія М., Синнестрьом С., Берток Я. Етика державної служби: запобігання конфлікту інтересів та вимоги до законодавства / пер. з англ. І.С. Чуприни. Київ : Центр адаптації державної служби до стандартів ЄС, 2010. 104 с.]. 
"Filtering" activities of the former public servants, the restriction after the termination of public service career is simultaneously connected with own regulated "red lines" (standards) the violation of which means "excessive" interference in "the private autonomy of the individual". In particular, term and scope of validity of the restriction are subjected to be standardized. Being guided by recognized standards on "corresponding cases and reasonable term" 22 , the legislator of different foreign countries regulated "the minimization of interference in the private autonomy of the individual", "the use of less intrusive measures of interference", "guarantee of a balance between private and public interests" in various ways. In the first instance, one should mark that the restriction doesn't cover any activity (work) of the former public servant but the very professional, which is associated with its previous public official activity. Such professional activity in turn should relate to the private area ("private sector", "private segment", "private and nongovernmental activity") and the functions, which were exercised by the former public servant at the post, or in the context of which he performed control functions. It doesn't signify the restriction of access of the former public servant to the private sector in a broad manner. The limits are statutorily applied to the part which is somewhat attributed to the former activity of ex-official. The lack of such "ties" makes the use of restriction resource impossible thus, the interference in "the private autonomy" of the former servant. The extension of the fundamentals of legal certainty significantly contributes to "tension reduction" in clarifying the objective specifics of this type of restriction. The practice of Spain is positively characterized as its legislation clearly marks that for the operation of the restriction "there shall be a connection in the following cases: in cases of senior officials, it concerns the decisions of immediate superiors and all chiefs of agencies subordinated based on delegation or re-delegation of authority towards corresponding campaigns; this is also about the cases when the above individuals take part in the activities of a collegiate body which decide on such campaigns". France provided a list of those institutions that use the provision under consideration, namely: " $<\ldots>$ posts in any corporations which either get grants from the government or enter into an agreement with local authorities or foreign governments, ... employment in property sale agencies or thrifts" ${ }^{23}$. The legislation of Mexico fixes a quite extensive list of institutions which are subjected to the restrictions after the termination of public service career of the individual ${ }^{24}$. While laws and regulations of Canada and Korea are

${ }^{22}$ Holovkin, B.M. (ed.) (2019). Corruption prevention: textbook. Kharkiv: Pravo [Запобігання корупції : підручник / Б.М. Головкін, В.Ф. Оболенцев, М.В. Романов та ін. ; за заг. ред. Б.М. Головкіна. Харків : Право, 2019. 296 с.].

${ }^{23}$ Suslova, I.M., Fluri, F., Badrak, V.V. (eds.) (2017). Parliamentary ethics in Ukraine. Realities of the needs, prospects (according to the research of the NGO "Center for Army, Conversion and Disarmament Studies" and the Institute of Social Technologies "Sociopolis"). Geneva, Kyiv [Парламентська етика в Україні. Реалії потреби, перспективи (за матеріалами дослідження ГО «Центр досліджень армії, конверсії та роззброєння» та Інституту соціальних технологій «Соціополіс») / пер. з англ. за заг. ред. І.М. Суслової, Ф. Флурі, В.В. Бадрака. Женева ; Київ, 2017. 56 c.].

${ }^{24}$ Suslova, I.M., Fluri, F., Badrak, V.V. (eds.) (2017). Parliamentary ethics in Ukraine. Realities of the needs, prospects (according to the research of the NGO "Center for Army, Conversion and Disarmament Studies" and the Institute of Social Technologies "Sociopolis"). Geneva, Kyiv [Парламентська етика в Україні. Реалії потреби, перспективи (за матеріалами дослідження 
oversaturated with evaluative provisions on the issue concerned: " $<\ldots>$ with whom the individual had important official relations", "which are tightly bound to the functions they have performed" 25 that drastically complicates law enforcement. Presenting details of the restriction after the termination of public service career (on employment, interest intermediation, civil matters), the legislator of different countries of the world uses several fixation models: "strict" with the prescription of possible participation of the former civil servants in presentation, representative events (for example, the USA experience) that looks very strict and, in such cases, one can suggest about some kind of "redundancy" of interference in the private life of the individual. At the same time, it is widespread "soft model" which defines the limits of interference in terms of the use of data obtained during the former professional public activity, employment and contractual relations after the termination of the public service career of the person. The latter model is well-founded (it covers "risky" range of relations), defined (it doesn't provide for "complete" or approximate to such interference) thus, eligible for spreading. The determinacy of such limits allows unifying the definition and application of the legislation on the relevant restriction by eliminating preconditions for the manifestation of unreasonable, subjective discretion hence, the alternative "overrun" the boundaries of minimal sound "interference in the private autonomy of the individual". "Reasonable time" of such restriction is subjected to be standardized. Taking into account "the value" of information, coat-tails, the experience of the previous public-professional activity of the individual, opportunities of their use with risk to ensure the implementation and protection of public interests, on the one hand, and minimization and intrusiveness of interference in "the private autonomy" of the very former servant, it seems feasible to consolidate a short period of restriction validity after the termination of public service career at the regulatory level. The lawmaking practice is characterized by the varying scenarios: the division of terms depending on the former post of the individual (for example, in Canada, the term for ex-ministers is two years since the termination of employment and one year-for other ex-officials), according to an element of restriction essence (for example, in Ukraine, the term is equal to one year towards employment, civil and representative relations with the participation of ex-servants, and it is unlimited towards the use of data obtained during the post), mono term (for example, it takes one year in Italy, the USA, two years - in Spain, three years - in Portugal, five years - in France). The specific nature of modern transformational state-building and law-making processes objectively causes the expediency of standardization of the very short terms of restriction validity that correlates with the keeping of balance between private

ГО «Центр досліджень армії, конверсії та роззброєння» та Інституту соціальних технологій «Соціополіс») / пер. з англ. за заг. ред. І.М. Суслової, Ф. Флурі, В.В. Бадрака. Женева ; Київ, 2017. 56 c.].

${ }^{25}$ Suslova, I.M., Fluri, F., Badrak, V.V. (eds.) (2017). Parliamentary ethics in Ukraine. Realities of the needs, prospects (according to the research of the NGO "Center for Army, Conversion and Disarmament Studies" and the Institute of Social Technologies "Sociopolis"). Geneva, Kyiv [Парламентська етика в Україні. Реалії потреби, перспективи (за матеріалами дослідження ГО «Центр досліджень армії, конверсії та роззброєння» та Інституту соціальних технологій «Соціополіс») / пер. з англ. за заг. ред. І.М. Суслової, Ф. Флурі, В.В. Бадрака. Женева ; Київ, 2017. 56 c.]. 
and public interests when using the relevant kind of restriction. In this respect, positive practice of those countries whose legislation fixes one-two year period of restriction validity is justified, and longer terms (incl. five-year term) are a kind of manifestation of "excessive" interference in "private autonomy" of the person and sometimes, taking into account the specifics of resident country, organizational aspect of the implementation of public service, discrimination of the individual based on his former activity. To find out the actual resource of the restriction after the termination of public service career, the issues of statutory regulation of the relations of responsibility for violation of this limit and, at the same time, the guarantee of appealing against its illegal application and redress gain importance. In this context, it is marked a benchmark experience of France on the legislative regulation of the relations of obligatory preliminary consultation (on the termination of public service career) of the individual by authorized supervisory agency regarding "admissibility", "inadmissibility", "admissibility under certain conditions" of a post in the private sector and procurement of a permit for holding the post that eliminates the preconditions for varying arbitrary interpretation and application of the provisions on restriction due to the mandatory nature. In case of violation of these requirements, the individual is found guilty of "illegal serving own interests" and brought to criminal liability ${ }^{26}$. While in Great Britain public servants shall notify about any attempts of external parties to offer them "future office in the private sector" 27 and in case of infraction, they are also may be deemed as ones committed a crime. There is a less restricted procedure of adherence to regulations on restriction (for example, the experience of Ukraine, Georgia) and administrative and criminal liability for breach of regulation. At the same time, in case of illegal application of the restriction to the former public servants, the legislation of most countries of the world involves guaranteeing of its appeal and compensation for damage that confirms a solid trend of the legislator's perception (however, with differing degrees of perception and detailed elaboration) and search for an optimal model of standardization of consolidation of all elements of "proportionality test" in regulating the principles of use of a unique resource of the relevant "special" restriction.

\section{Conclusions}

In the context of active use of a unique resource of the restriction after the termination of public service career as an instrument for corruption prevention in the private sector, "the proportionality test" in its broad sense, as the mix of several obligatory complex elements, should act as the basis for shaping model of its legal regulation which is perfect in content and effective in use. The author proposes to consider the standards

${ }^{26}$ Villoriia, M., Synnestrom, S., Bertok, Ya. (2010). Civil service ethics: prevention of conflict of interests and requirements for the legislation. Kyiv: Center for Civil Service Adaptation to EU Standards [Віллорія М., Синнестрьом С., Берток Я. Етика державної служби: запобігання конфлікту інтересів та вимоги до законодавства / пер. $з$ англ. І.С. Чуприни. Київ : Центр адаптації державної служби до стандартів ЄС, 2010. 104 с.].

${ }^{27}$ Villoriia, M., Synnestrom, S., Bertok, Ya. (2010). Civil service ethics: prevention of conflict of interests and requirements for the legislation. Kyiv: Center for Civil Service Adaptation to EU Standards [Віллорія М., Синнестрьом С., Берток Я. Етика державної служби: запобігання конфлікту інтересів та вимоги до законодавства / пер. з англ. І.С. Чуприни. Київ : Центр адаптації державної служби до стандартів СС, 2010. 104 с.]. 
of such regulation as follows: legislative (along with a simultaneous correlation with the codes of conduct for public servants) consolidation of the provision of absolute determination of the content (excluding the opportunity to use evaluative provisions) towards all elements of the mechanism of the specific restriction; absolute determinacy of the fixed "basic" standards-definitions; unification of the provisions about the subject of restriction with the elimination of any preconditions for possible discrimination; specification of the scope for "interference" including "the former" public service of an individual, as well as the minimization of restriction validity (one year); standardization of the provisions on the legitimate goal of the restriction, the content of which is relevant to all elements of the latter; detailed elaboration of the regulation of the procedure for the individual's employment after the termination of public service career; corresponding tie between a subtle state and instructions for guaranteeing appeals and redress related to the use of the restriction resource.

\title{
«ТЕСТ НА ПРОПОРЦЙНІСТЬ» У ПРАВОВОМУ РЕГУЛЮВАННІ ОБМЕЖЕННЯ ПІСЛЯ ПРИПИНЕННЯ ПУБЛІЧНОЇ СЛУЖБИ: ПОШУК ОПТИМАЛЬНОЇ МОДЕЛІ
}

\author{
Тетяна Коломоєць, \\ декан юридичного факультету \\ Запорізького національного університету, \\ доктор юридичних наук, професор, \\ член-кореспондент Національної академії правових наук України, \\ заслужений юрист України \\ orcid.org/0000-0003-1101-8073 \\ t_deputy@ukr.net
}

Мета - обтрунтування доцільності формування обмеження після припинення публічної служби, підгрунтям якої $\epsilon$ «тест на пропориійність», та виокремлення єдиних стандартів закріплення його елементів.

Методи дослідження. Роботу виконано на підставі загальнонаукових і спеціальних методів наукового пізнання. Діалектичний метод як базовий дав змогу з'ясувати сутність тесту на пропориійність, його вузьке й широке розуміння, обтрунтувати його базове значення для моделі правового регулювання відповідного обмеження. Формально-логічні методи дали змогу вивчити проблемні аспекти унормування засад його обмеження, щзо зумовило «дефектність» його розуміння та застосування. За допомогою логіко-семантичного методу конкретизовано понятійний ряд, завдяки порівняльно-правовому - особливості сприйняття елементів тесту на пропориійність у нормотворчій практииі країн світу. За допомогою прогнозування та моделювання сформульовано пропозииї щзодо базових стандартів моделі відповідного правового регулювання.

Результати. Проаналізовано основні доктринальні підходи до розуміння тесту на пропориійність, його вузького й широкого варіантів, доведено його базову роль для формування моделі правового регулювання відповідного обмеження як інструменту запобігання корупиіі у правовій сфері. На підставі аналізу нормотворчої практики країн світу доведено існування стійкої тендениї щодо сприйняття (несистемного, різного ступеня проявуй фіксаиії) елементів тесту на пропориійність у правовому регулюванні відповідного обмеження, наслідком чого є 
надмірне втручання у приватну автономію особи, ї̈ дискримінація. Виокремлюються конкретні приклади тематичної нормотворчої практики різних країн та формулюються стандарти моделі правового регулювання відповідного обмеження.

Висновки. В умовах активного використання унікального ресурсу обмежсння після припинення публічної служби як інструменту запобігання корупиї у приватній сфері підтрунтям для формування досконалої за змістом та ефективної в застосуванні моделі його правового регулювання має слугувати «тест на пропориійність» у його иирокому розумінні як поєднання декількох обов'язкових комплексних елементів. Запропоновано такі стандарти иього регулювання: 1) законодавче (з одночасною кореляцію з кодексами поведінки публічних службовців) закріплення положень абсолютно визначеного змісту (з виключенням можливості використання оціночних положень) стосовно всіх елементів механізму відповідного обмеження; 2) абсолютну визначеність закріплених базових норм-дефініцій; 3) уніфікацію положень щэодо суб 'єкта обмеження з усуненням будь-яких передумов длямможливої дискримінаиії; 4) абсолютну визначеність сфер втручання з прямим зв'язком із «колишньою» публічною службою особи, а також мінімізацією строку дї обмеження (один рік); 5) унормування положень про легітимну мету обмеження, зміст якої є релевантним усім елементам змісту останнього; 6) деталізацію регулювання процедури працевлаштування особи після припинення публічної служби; 7) кореспондуючий зв'язок делікатних положень і приписів гарантування оскарження та відикодування шкоди, пов'язаних із використанням ресурсу обмеження.

Ключові слова: корупція у приватній сфері, фільтр, доречність, необхідність, баланс публічних і приватних інтересів, законодавство, стандарти, елементи. 